\title{
THE IMPACT OF ORGANIZATIONAL SUPPORT AND JUSTICE PERCEPTION ON COMMITMENT AND INTENTION TO QUIT: AN EMPIRICAL STUDY ON TURKISH STATE UNIVERSITIES
}

\author{
Serhat ERAT \\ Oya ERDIL \\ Hakan KITAPÇI
}

Gebze Institute of Technology, Turkey

\begin{abstract}
In recent years, the number of universities has increased. This situation has raised the level of competition among state universities as well as private universities. The facilities offered by universities and the perception of justice cause academicians to question their work satisfaction and commitment to their universities. The purpose of this study is to identify the impact organizational support and perception of justice has on the commitment of academicians to their institutions and their intention to quit. Over a thousand academicians participated in our study. Our analysis results conclude that perceived organizational support and justice significantly affect commitment and the intention to quit.
\end{abstract}

Keywords: Organizational Justice, Organizational Support, Organizational Commitment, Intention to quit.

\section{INTRODUCTION}

Recently, with the increase in the number of universities in Turkey, faculty members have considerably more opportunities to choose among. Their effectiveness, productivity and commitment even more depend on the variety of facilities provided by the universities and the perception of justice in their working environments. Leaving faculty members means the loss of immense amount of experience, knowledge and teaching capacities for higher education institutions. Especially newly established universities are in urgent need of productive and experienced academicians to achieve national and international status and to recruit high quality students.

Within the institutions with high quality academicians, any possible ill-treatment towards individuals and unfavorable conditions in working places might cause these faculty members to leave their institutions with possible negative effects on their organizations. Universities must enhance the commitment of their employees to avoid these bad outcomes.

Human resource practices enhance organizational commitment by raising employees' commitments to their institutions and performances, which is of great importance especially in knowledge intensive production of goods and services (Kwon, Bar and Lawler, 2010). To appreciate organizational justice is vital for organizations because organizational justice is important for employees' job satisfaction, organizational commitment, and intention to quit (DeConinck \& Stilwell 2004).

Main aim of our study is to develop a model to investigate the effect of organizational support and perception of justice on the organizational commitment and intention to quit. Especially, our study examines above mentioned relationships within the framework of Turkish state universities and enhances the literature by exclusively focusing on education and R\&D services, which is the knowledgeintensive production in nature. 


\section{LITERATURE REVIEW}

\section{Justice Perception}

Organizational justice is defined as an employee's perception to fairness in the work environment, (Elovainio et al., 2003) and their perception towards the fairness of their awards (pay) and processes applied (Hubbell and Chory-Assad, 2005). In international literature, researchers set forth that organizational justice perception is formed of two dimensions; distributive justice, and procedural justice (Cropanzono and Greenberg, 1997:317). Distributive justice represents an employee's perception to fairness associated with awards, benefit, amount and type of pay. Procedural justice reflects an employee's perception to fairness of the processes that identify awards, benefits, and pay. In other words, distributive justice focuses on results, while procedural justice focuses on processes and means (Greenberg, 1990:561; Sweeney and McFarlin, 1993, 25).

Subject-related studies, referred to in literature, state that the intention to quit is higher in employees that believe profits are not distributed fairly within the organization (Alexander and Ruderman, 1987; Lipponnen et al. 2004: 288). Konovsky and Cropanzano (1991) also reported that employees' perception of justice in the workplace has an adverse effect on their intention to quit. Organizational justice is related to numerous concepts, and affects an employee's decision to keep their job, or resign (Töremen F., 2010: 11). An employee's perception of fairness regarding the rules and processes applied in the organization has an important effect on the pride they take in working for that organization or their intention to quit (Altıntaş, F, C, 2006: 14). There is a correlation between justice and the intention to quit. There is a correlation between the intention to quit and both distributive justice and procedural justice; the correlation between procedural justice and the intention to quit is stronger (Robbins et al. 2000). Employees that have a positive perception of organizational justice will be more loyal to their organization (Sweeney and McFarlin, 1993); whereas, employees that have a negative perception of organizational justice, in other words, have a perception of organizational injustice or unfairness, may display resigning behaviors (Aquino and Hom, 1997).

A study conducted on the education sector regarding the perception of organizational commitment and organizational justice concluded that there was a positive significant relationship between distributive justice and the components of organizational commitment (Demircan, 2003: 110). Orpen reported that when an organization achieves both procedural justice and distributive justice, the employees' level of organizational commitment is higher (Orpen, 1994: 136). The perception of justice increases job satisfaction, organizational commitment, and performance; ultimately, decreases the intention to quit (Hom and Griffeth, 1991; Tett and Meyer, 1993). In their study, Martin et al. concluded that employees that believed they were not receiving recompense for their works had a lower level of organizational commitment in comparison to those that believed they were receiving recompense for their works (Martin and Bennett, 1996:84). A study, conducted on employees working for the tourism sector in Turkey and Poland, concluded that organizational justice is effective on organizational commitment. However, it is set forth that this effect varies based on the country and culture of the organization (Yaylı and Çöp; (2009: 181).

Hypotheses are shaped as below based on the thoughts stated above.

$\mathbf{H}_{1}$ : Distributive justice perception has a positive effect on affective commitment.

$\mathbf{H}_{2}$ : Distributive justice perception has a positive effect on continuous commitment.

$\mathbf{H}_{3}$ : Distributive justice perception has a positive effect on normative commitment.

$\mathbf{H}_{4}$ : Distributive justice perception has a negative effect on intention to quit.

$\mathbf{H}_{5}$ : Procedural justice perception has a positive effect on affective commitment.

$\mathbf{H}_{6}$ : Procedural justice perception has a positive effect on continuous commitment.

$\mathbf{H}_{7}$ : Procedural justice perception has a positive effect on normative commitment.

$\mathbf{H}_{\mathbf{8}}$ : Procedural justice perception has a negative effect on intention to quit. 


\section{Perception of Organizational Support}

Eisenberger et al. (1986) define that organizational support as the degree of recognition of organization of its employee's efforts, and the level of attention of its employees' happiness, which have employees form general beliefs towards their organizations. Additionally, the perceived organizational support is defined as employees' perception towards the level of attention paid by their organizations on the importance of employee participation and an employee's well-being, as well as the perceptions that whether an organization provides employees with facilities benefiting them voluntarily. In theory, employees with a high perception level of organizational support have a tendency to display behaviors that benefit the organizations. Shaffer et al. (2001) define organizational support as trust that makes employees to stay in their current position, and remain committed to their organization, in addition to the financial benefits employees receive from their organizations. The Perceived Organizational Support (POS) theory uses the social change perspective to explain employee-organization relations (Loi et al., 2006). According to the social change theory, there is a strong relationship between organizational support and affective commitment (Shore and Tetrick, 1991).

Empirical studies on the subject conclude that high organizational commitment, job satisfaction, job performance and organizational citizenship behavior, and a low intention to quit are among the positive results of high level of perceived organizational support (Eisenberger et al., 1990; Moorman et al.,1998; Rhoades and Eisenberger, 2002; Settoon et al., 1996). One of the most important result of perceived organizational support is stronger organizational commitment (Christopher, 1994). Perceived Organizational Support is the degree to which employees feel secure and the organization behind them. Employees that constantly feel the support of their organizations are more devoted to their jobs, and are less likely to quit (Ozdevecioglu, 2003).

Organizations with employees that have a high level of support perception are more attractive, and because employees do not seek alternative employment opportunities, the possibility of leaving is a lot lower (Cropanzona et al. 1997; Allen et all, 2003). Organizational support persuade employees to fulfill the objectives of the organization, which reduce the possibility of resignations (Y1ldiz, 2008). Grandey (1997) reports that there is a significant and inverse relationship between employees' perceived organizational support and their intention to quit. Randall et al. find that there is a negative relationship between organizational support and the intention to quit (Randall et al., 1999).

We develop a number of hypotheses based on the thoughts and conclusions drawn from the related literature.

$\boldsymbol{H}_{9}:$ Organizational support perception has a positive effect on affective commitment.

$\boldsymbol{H}_{10}$ : Organizational support perception has a positive effect on continuous commitment.

$\boldsymbol{H}_{11}$ : Organizational support perception has a positive effect on normative commitment.

$\boldsymbol{H}_{12}$ : Organizational support perception has a negative effect on intention to quit.

\section{THE METHODOLOGY OF THE STUDY}

\section{Research Model}

Figure 1 shows our theoretical model in which we outline our approach to the relationships among distributive justice, procedural justice, organizational support, organizational commitment and intention to quit.

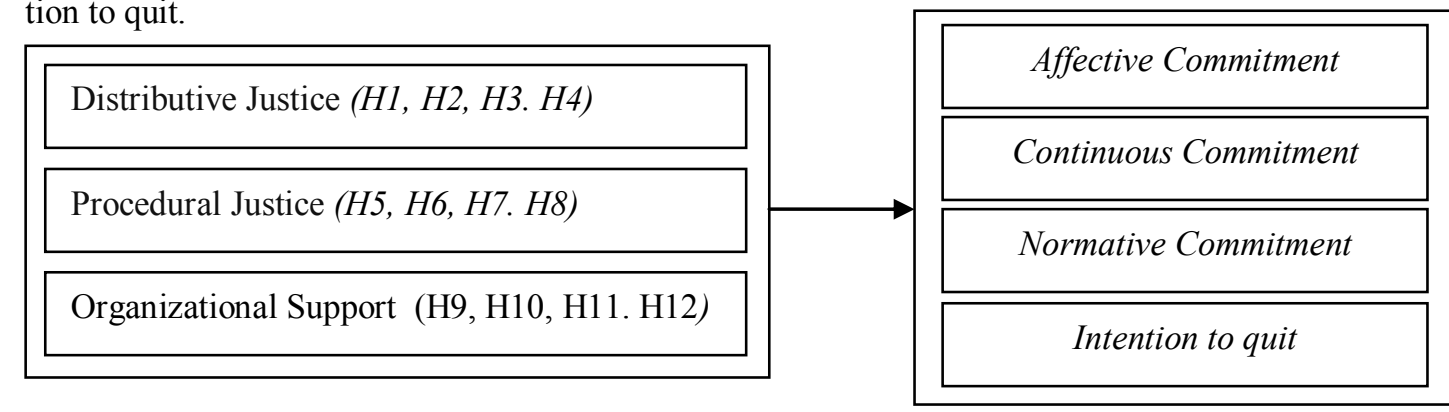

Figure 1: Research Model 


\section{Data Collection Method and Sample Structure}

All academic personnel (faculty members and research/teaching assistants) at state universities in Turkey are included in this study. The research questionnaire were sent to 6109 e-mail addresses of academic personnel within the sample group who might be willing to participate in the study, selected via a collection process using the worldwide web. 892 of these e-mails sent were returned due to the email addresses being incorrect or unpermitted by their system. The collection process lasted a month; 1043 academic personnel responded to the 5217 e-mails sent. This sampling method is preferred by some researchers in order to achieve homogeneity (see, Calder et al., 1981). Provided that the main population is well-determined, web-based questionnaires have a selection function that brings together those that directly represent the researched subject, or those that are closely related (Corbitt et al., 2003). The turnaround rate is $19.9 \%$, which is sufficient based on questionnaires conducted over the Internet via e-mail (Schonlau et al., 2002). The turnaround rate of web-based questionnaires is relatively lower in comparison to other questionnaire types (Sax, et al., 2003).

The demographic characteristics of our sample for this study are as follows. 1043 academic personnel responded to our survey. $42 \%$ of the participated academic personnel are tenure track faculty (full professors, associate professors, assistant professors) and $52 \%$ of the responded are non-tenure track faculty, and 6\% do not disclose their positions. $62.1 \%$ (648 individuals) of participants are male, and $37.9 \%$ (395 individuals) are female. 3\% (34 individuals) of the $42 \%$ faculty members are professors, $7 \%$ (78 individuals) are associate professors, and 31\% (324 individuals) are assistant professors. Among the non-tenure track faculty, 24\% (252 individuals) are research/teaching assistants, 21\% (222 individuals) are lecturers, $3 \%$ (31 individuals) are prelectors, $4 \%$ (41 individuals) are specialists.

\section{Scales, Factor Analyses, and the Reliability of Scales}

Scales whose validity and reliability have been tested by different studies on international literature are used in this study. A fifteen-question procedural justice perception scale, and a five-question distributive justice perception scale, developed by Niehoff and Moorman (1993), are used as the justice perception scales. An eight-question scale, developed by Eisenberger et al., (2002), is used as the organizational support perception scale. The organizational commitment scale, developed by Meyer and Allen, (1997), comprises of a seven-question affective commitment, six-question continuous commitment, and seven-question normative commitment. A five-question scale, developed by Cammann and All, (1979), and Bluedorn (1982), is used as the intention to quit scale. All variables comprise of a five -point Likert scale; "1" being "strongly disagree," and " 5 " being "strongly agree." We employ a SPSS program to identify the factor structure, analyze the relationship between variables, and test the hypotheses.

Justice perception, organizational support perception, and job satisfaction expressions are subjected to individual varimax rotation factor analysis in order to present data in a more significant and simplified form; results obtained are in line with those stated in literature. Our results imply that the two subscales that determine the justice perception of employees (procedural and distributive justice perception) are loaded on two separate factors, and organizational support perception is based on one dimension. Commitment is separated as affective, continuous, and normative commitment. Table 1 illustrates the factor loads of Distributive Justice Perception (DJP), Procedural Justice Perception (PJP), Organizational Support Perception (OSP), Continuous Commitment (CC), Normative Commitment (NORM), Intention to quit (ITQ), and Affective Commitment (EC). 
Table 1. The results of exploratory factor analysis with varimax rotation

\begin{tabular}{|c|c|c|c|c|c|c|c|}
\hline & DJP & PJP & OSP & $\mathrm{CC}$ & NORM & ITQ & $\mathrm{EC}$ \\
\hline DJP 1 & .824 & & & & & & \\
\hline DJP 2 & .889 & & & & & & \\
\hline DJP 3 & .765 & & & & & & \\
\hline PJP 1 & & .752 & & & & & \\
\hline PJP 2 & & .810 & & & & & \\
\hline PJP 3 & & .808 & & & & & \\
\hline PJP 4 & & .802 & & & & & \\
\hline PJP 5 & & .777 & & & & & \\
\hline OSP1 & & & .805 & & & & \\
\hline OSP 2 & & & .831 & & & & \\
\hline OSP 3 & & & .797 & & & & \\
\hline OSP 4 & & & .792 & & & & \\
\hline OSP 5 & & & .793 & & & & \\
\hline OSP 6 & & & .775 & & & & \\
\hline $\mathrm{CC} 1$ & & & & .741 & & & \\
\hline $\mathrm{CC} 2$ & & & & .814 & & & \\
\hline $\mathrm{CC} 3$ & & & & .786 & & & \\
\hline $\mathrm{CC} 4$ & & & & .665 & & & \\
\hline CC 5 & & & & .681 & & & \\
\hline NORM 1 & & & & & .792 & & \\
\hline NORM 2 & & & & & .751 & & \\
\hline NORM3 & & & & & .828 & & \\
\hline NORM4 & & & & & .775 & & \\
\hline NORM5 & & & & & .705 & & \\
\hline ITQ 1 & & & & & & .768 & \\
\hline ITQ 2 & & & & & & .811 & \\
\hline EC 1 & & & & & & & .812 \\
\hline EC 2 & & & & & & & .764 \\
\hline EC 3 & & & & & & & .691 \\
\hline
\end{tabular}

Explained total variance: $\% 71$

\section{Relational Analysis of Variables and Testing Hypotheses}

Table 2 reports some summary statistics such as mean, standard deviation and Cronbach's alpha values of the variables used in correlation analysis.

Table 2: The descriptive statistics (mean, standard deviation, and Cronbach Alpha) and correlation analysis results of variable

\begin{tabular}{|l|l|l|c|c|c|c|c|c|c|c|}
\hline & & Mean & Sd & alfa & 1 & 2 & 3 & 4 & 5 & 6 \\
\hline 1 & $\begin{array}{l}\text { Distributive } \\
\text { Justice }\end{array}$ & 3.09 & 1.06 & 0.84 & & & & & & \\
\hline 2 & $\begin{array}{l}\text { Procedural } \\
\text { Justice }\end{array}$ & 2.76 & 1.13 & 0.94 & $.418(* *)$ & & & & & \\
\hline 3 & $\begin{array}{l}\text { Organiza- } \\
\text { tional Support }\end{array}$ & 2.92 & 1.02 & 0.94 & $.422(* *)$ & $.717(* *)$ & & & & \\
\hline 4 & $\begin{array}{l}\text { Continuance } \\
\text { Commitment }\end{array}$ & 3.03 & .89 & 0.79 & -.013 & -.010 & .006 & & & \\
\hline 5 & $\begin{array}{l}\text { Normative } \\
\text { Commitment }\end{array}$ & 2.85 & .98 & 0.87 & $.250(* *)$ & $.365(* *)$ & $.408(* *)$ & $.089(* *)$ & & \\
\hline 6 & $\begin{array}{l}\text { Affective } \\
\text { Commitment }\end{array}$ & 3.17 & .94 & 0.69 & $.184(* *)$ & $.158(* *)$ & $.205(* *)$ & -.059 & $.235(* *)$ & \\
\hline 7 & $\begin{array}{l}\text { Intention to } \\
\text { Quit }\end{array}$ & 2.83 & 1.11 & 0.76 & $-.265(* *)$ & $-.365(* *)$ & $-.406(* *)$ & $-.106(* *)$ & $-.451(* *)$ & $-.289(* *)$ \\
\hline
\end{tabular}

$* * P<0.01$ 
Correlation coefficients indicate that there is a positive relationship among organizational support, distributive justice, and procedural justice, normative commitment and affective commitment $(\mathrm{P}<0.01)$; there was a negative relationship with the intention to quit $(\mathrm{P}<0.01)$. The reliability coefficient of variables was $0.84,0.94,0.94,0.79,0.87,0.69$, and 0.76, respectively. The Cronbach Alpha of variables are larger than the expected value, 0.60 (Nunnally, 1978). We can safely conclude that that the questions are reliable.

Table 3: Multiple regression analysis for testing hypotheses.

\begin{tabular}{|c|c|c|c|c|c|c|c|c|}
\hline & \multicolumn{2}{|c|}{$\begin{array}{c}\text { Model 1 } \\
\text { Affective Com- } \\
\text { mitment }\end{array}$} & \multicolumn{2}{|c|}{$\begin{array}{c}\text { Model } 2 \\
\text { Continuance } \\
\text { Commitment }\end{array}$} & \multicolumn{2}{|c|}{$\begin{array}{c}\text { Model } 3 \\
\text { Normative Com- } \\
\text { mitment }\end{array}$} & \multicolumn{2}{|c|}{$\begin{array}{c}\text { Model } 4 \\
\text { Intention to Quit }\end{array}$} \\
\hline & Beta & $t$ & Beta & $t$ & Beta & $t$ & Beta & $t$ \\
\hline $\begin{array}{l}\text { Distributive } \\
\text { Justice }\end{array}$ & $.119 * *$ & 3.514 & - & - & $.076 *$ & 2.418 & $-.096 * *$ & -3.049 \\
\hline $\begin{array}{l}\text { Procedural } \\
\text { Justice }\end{array}$ & -.005 & -.120 & - & - & $.132 * *$ & 3.214 & $-.129 * *$ & -3.163 \\
\hline $\begin{array}{l}\text { Organizational } \\
\text { Support }\end{array}$ & $.159 * *$ & 3.601 & - & - & $.281 * *$ & 6.860 & $-.273 * *$ & -6.665 \\
\hline $\begin{array}{r}R^{2} \\
\text { Adjusted } R^{2} \\
F \\
\text { Sig. }\end{array}$ & \multicolumn{2}{|c|}{$\begin{array}{c}.054 \\
.051 \\
19.635 \\
.000\end{array}$} & \multicolumn{2}{|c|}{$\begin{array}{c}- \\
- \\
- \\
.883\end{array}$} & \multicolumn{2}{|c|}{$\begin{array}{c}.182 \\
.180 \\
77.005 \\
.000\end{array}$} & \multicolumn{2}{|c|}{$\begin{array}{c}.184 \\
.181 \\
77.932 \\
.000\end{array}$} \\
\hline
\end{tabular}

$* * P<0,01$
$* P<0,05$

Four different regression models are employed to test the above-mentioned hypotheses. Distributive justice, procedural justice, and organizational support variables are accepted as independent variables for all four models (Table 3). The dependent variable in Model 1 is affective commitment, the dependent variable in Model 2 is continuous commitment, the dependent variable in Model 3 is normative commitment, and the dependent variable in Model 4 is the intention to quit. Model $1(\mathrm{~F}=19.635$, $\mathrm{P}<0.01)$, Model $3(\mathrm{~F}=77.005, \mathrm{P}<0.01)$, and Model $4(\mathrm{~F}=77.932, \mathrm{P}<0.01)$ are significant, and Model 2 $(\mathrm{P}>0.01)$ is insignificant.

In Model 1, the coefficients on distributive justice $(\beta=.119 ; \mathrm{P}<0.01)$ and organizational support $(\beta=.159 ; \mathrm{P}<0.01)$ are statically significant and positive, which imply that higher distributive justice and organizational support enhances affective commitment. Procedural justice had no effect on affective commitment. Thus, hypotheses H1 and H9 are accepted, the hypothesis H5 is dismissed.

Since none of the coefficients on independent variables are statistically significant and $\mathrm{F}$ value for Model 2 is insignificant, hypotheses H2, H6, and H10 are also dismissed.

In Model 3, the estimated coefficients on the distributive justice $(\beta=.076 ; \mathrm{P}<0.05)$, procedural justice $(\beta=.132 ; \mathrm{P}<0.01)$, and organizational support $(\beta=.281 ; \mathrm{P}<0.01)$ are all statistically significant and positive. These results imply that higher levels of both types of perception of justice and organizational support raise normative commitment. Therefore, hypotheses H3, H7, and H11 are all accepted.

Finally in "Intention to Quit" $\operatorname{model}($ Model 4), all estimated coefficients, distributive justice $(\beta=-$ $.096 ; \mathrm{P}<0.01)$, procedural justice $(\beta=-.129 ; \mathrm{P}<0.01)$, and organizational support $(\beta=.273 ; \mathrm{P}<0.01)$, have expected signs and are statistically significant. Our estimation results mean that higher levels of both types of perception of justice and organizational support reduce the intention to quit. Hypotheses H4, H8, and H12 are, thus, accepted. Table 4 illustrates the results and explanations of multiple regression analysis and hypotheses testing. 
Tablo 4: The results of hypotheses

\begin{tabular}{|l|c|}
\hline $\boldsymbol{H}_{1}$ : Distributive justice perception has a positive effect on affective commitment. & Accept \\
\hline $\boldsymbol{H}_{2}:$ Distributive justice perception has a positive effect on continuous commitment. & Not Accept \\
\hline $\boldsymbol{H}_{3}:$ Distributive justice perception has a positive effect on normative commitment. & Accept \\
\hline $\boldsymbol{H}_{4}:$ Distributive justice perception has a negative effect on intention to quit. & Accept \\
\hline $\boldsymbol{H}_{5}:$ Procedural justice perception has a positive effect on affective commitment. & Not Accept \\
\hline $\boldsymbol{H}_{6}:$ Procedural justice perception has a positive effect on continuous commitment. & Not Accept \\
\hline $\boldsymbol{H}_{7}:$ Procedural justice perception has a positive effect on normative commitment. & Accept \\
\hline $\boldsymbol{H}_{8}:$ Procedural justice perception has a negative effect on intention to quit. & Accept \\
\hline $\boldsymbol{H}_{9}:$ Organizational support perception has a positive effect on affective commitment. & Accept \\
\hline $\boldsymbol{H}_{10}:$ Organizational support perception has a positive effect on continuous commitment. & Not Accept \\
\hline $\boldsymbol{H}_{11}:$ Organizational support perception has a positive effect on normative commitment. & Accept \\
\hline $\boldsymbol{H}_{12}:$ Organizational support perception has a negative effect on intention to quit. & Accept \\
\hline
\end{tabular}

\section{CONCLUSIONS and RECOMMENDATIONS}

Our study mainly investigates the relationship between Organizational Support Perception and Organizational Commitment, and the relationship between Organizational Support Perception and the Intention to Quit. It also considers those relationships including various sub-scales of these measures. Varimax rotation factor analysis set forth organizational support and intention to quit variables. While factor analysis helps us to separate organizational justice perception into distributive and procedural justice, organizational commitment is classified as affective, continuous, and normative commitment.

Numerous studies support results related to the regression models developed to test the hypotheses set forth. There are studies available that set forth the relationship between the justice perception of employees and their organizational commitment (Sweeney and McFarlin, 1997; Folger and Konovsky, 1989; Lam et al., 2002; Barling and Phillips, 1992; Masterson et al. 2000), and the effect the concept of justice with its dimensions has on the intention to quit (Sweeney and McFarlin, 1997; Harris et al., 2007; Colquitt et al., 2001; Hopkins and Weathington, 2006; Olkkonen and Lipponen, 2006).

The study shows that organizational support has negative effect on intention to quit. These results were supported by those of previous studies done by other researchers (Cropanzona and all (1997), Eisenberger et al (2002), Allen et al (2003) ve Hui and al (2007)).

As research results show that organizational support has positive effect on organizational commitment. This result were supported by Allen et all (2003), Rhoades, Eisenberger, and Armeli (2001) and Pack et al. (2007).

Our estimation results listed above are mainly consistent with the literature reviewed earlier. Our results indicate that while academic personnel with both high levels of distributive justice perception and procedural justice perception are likely to have more affective commitment and normative commitment and less intention to quit, distributive justice perception of academicians has no effect on continuous commitment.

We also find very similar results for the effect of organizational support perception of academicians on the affective commitment, normative commitment, continuous commitment, and intention to quit. It is important to note that one of the most striking conclusions of this study is that the Organizational Support Perception and the Organizational Justice Perception of academicians have no effect on their continuous commitment in Turkish state universities.

Overall, by investigating the effect organizational support and justice perception on the commitment and quittal intention of employees with all sub-variables, our study have a potential to guide related studies to be conducted on similar subjects. Moreover, the fact that the rate of participation in this 
study is quite high makes our results more reliable and accurate and also renders it more beneficial for researchers will-be conducting similar studies.

Note that, however, our study has some limitations, too. Firstly, our sample is restricted to the employees of state universities. Future line of research can be extended by adding the employees of private universities to the sample. Secondly, this study can be performed within the different regions. Thirdly, a number of other related variables such as organizational identification, occupational commitment, organizational citizenship, job satisfaction and organizational stress could be added to the study for future research. 


\section{REFERENCES}

Alexander, S., and Ruderman, M. (1987). "The Role of Procedural and Distributive Justice in Organizational Behavior”. Social Justice Research, Vol. 1, No. 2 177-198.

Allen, D., Shore, L. M., ve Griffeth, R. W. (2003), "The role of Perceived Organizational Support and Supportive Human Resource Practices in the Turnover Process", Journal of Management, 29(1), Pp. 99-118.

Altıntaş, Çınar Füsun (2006) , "Bireysel Değerlerin Örgütsel Adalet Ve Sonuçları İlişkisinde Yönlendirici Etkisi: Akademik Personel Üzerinde Bir Analiz”, İşletme Fakültesi Dergisi, Cilt 7, Sayı 2, 2006, s. 19-40.

Aquino D. G. And Hom, P. W. (1997), "Integrating Justice Constructs into the Turnover Process: A Test of Referent Cognitions Model", Academy of Management Journal, Vol. 40, No.5, p. 1208-1227.

Barling, J., and Phillips, M., (1992). "Interactional, Formal, and Distributive Justice in the Workplace: An Exploratory Study", The Journal of Psychology, Vol. 127, No. 6, Pp. 649-656.

Bluedorn, A.C., (1982), "A unified model of turnover from organizations", Human Relations, 35, Pp.135-153

Calder, B.J., PhilipS, L.W. and Tybout, A.M. (1981). "Designing Research for Application". Journal of Consumer Research, Vol. 8, 197-207.

Calder, B.J., PhilipS, L.W. ve Tybout, A.M. (1981). Designing Research for Application. Journal of Consumer Research, Vol. 8, 197-207.

Cammann, C., Fichman, M., Jenkins, D. and Klesh, J., (1979). "The Michigan Organizational Assessment Questionnaire", Uupublished Manuscript, University of Michigan, Ann Arbor Michigan, Pp. 146.

Christopher, O., (1994), "The Effects of Exchange Ideology on the Relationship Between Perceived Organizational Support and Job Performance", Journal of Social Psychology, 134(3), pp. 407-408.

Colquitt, J.A., Conlon, D.E., Wesson, M.J., Porter, C.O.L.H., and Yee NG, K., (2001). "Justice at the Millennium: A Meta-Analytic Review of 25 Years of Organizational Justice Research", Journal of Applied Psychology, 86(3), Pp. 425-445.

Corbitt, B.J., Thanasankit, T. and Han, Y. (2003). "Trust and E-Commerce: A Study of Consumer Perceptions". Electronic Commerce Research and Applications, Vol. 2, No.3, 203-215.

Cropanzano, R., and Greenberg, J. (1997), "Progress in organizational justice: Tunneling through the maza". In C.L.Cooper\& I.T.Robertson (Eds), International Review of Organizational Psychology, 12, 317-371.

Cropanzano, Russell; John C., Howes; Alicia A. Grandey and Paul TOTH; (1997), .The Relationship of Organizational Politics and Support to Work Behaviors, Attitudes, and Stress., Journal of organizational Behavior, (18)2, Pp. 159-180.

Demircan, Nigar (2003), Örgütsel Güvenin Bir Ara Değişken Olarak Örgütsel Bağlllık Üzerindeki Etkisi: Eğitim Sektöründe Bir Uygulama, Yayımlanmamış Doktora Tezi, Gebze Yüksek Teknoloji Enstitüsü, Sosyal Bilimler Enstitüsü, Gebze.

DeConinck, B. J. \& Stilwell, C.D. (2004). Incorporating Organizational Justice, Role States, Pay Satisfaction and Supervisor Satisfaction in A Model of Turnover Intentions. Journal of Business Research, 57, 225-231.

Eisenberger, R., Huntington R., Hutchison S. and Sowa, D. (1986). "Perceived Organizational Support". Journal of Applied Psychology, 7:500-507.

Eisenberger, Robert., Peter Fasola and Valerie Davis- LaMastro, (1990), "Perceived Organizational Support And Employee Diligene, Commitment, and Innovation", Journal of Applied Psychology, Vol. 75, (1), Pp.51-59.

Eisenberger, R., Stinglhamber, F., Vandenberghe, C., Sucharski, I.L. and Rhoades, L. (2002). Perceived Supervisor Support: Contributions to Perceived Organizational Support and Employee Retention. Journal of Applied Psychology, 87(3), 565-573.

Eisenberger R (2002). "Perceived Supervisor Support: Contribution to Perceived Organizational Sup- 
port and Employee Retention", Journal of Applied Psychology. 87(3): 565-573.

Elovainio, M., Kivimaki, M., Vahtera, J., Virtanen, M., and Keltikangas- Jarvinen, L., (2003). "Personality as a moderator in the relations between perceptions of organizational justice and sickness absence", Journal of Vocational Behavior, Vol. 63, Pp. 379-395.

Folger, R., and Konovsky, M.A., (1989). "Effects of Procedural and Distributive Justice on Reactions to Pay Raise Decisions”, Academy of Management Journal, Mar 1989, 32, 1, Pp. 115-130.

Grandey, J., (1997), "The relationship of organizational politics and support to work behaviors, attitudes, and stres", Journal of Organizational Behavior, 18(2), pp. 159-180.

Greenberg, Jerald (1990), “Organizational Justice: Yesterday, Today, and Tomorrow”, Journal of Management, Vol. 16, No. 2, Pp. 399-432.

Harris, K. J., Andrews, M. C., and Kacmar, K. M., (2007). "The Moderating Effects of Justice on the Relationship Between Organizational Politics and Workplace Attitudes", Journal of Business and Psychology, Vol. 22, Pp. 135-144.

Hom, Peter and Grifeth, R.W. (1991). "Structural Equations Modeling Test of a Turnover Theory: Cross-Sectional and Longitudinal Analyses”. Journal of Applied Psychology, 76, 350-366.

Hopkins, S. M., and Weathington, B. L., (2006). "The Relationship Between Justice Perceptions, Trust, and Employee Attitudes in Downsized Organization", The Journal of Psychology, Vol. 140, No. 5, Pp. 477-498.

Hubbell, A. P., and Chory-Assad, R. M., (2005). "Motivating Factors: Perceptions of Justice and Their Relationship with Managerial and Organizational Trust", Communication Studies, Vol. 56, No. 1, Pp. 47-70.

Hui, C., Wong A. ve Tjosvold D. (2007). "Turnover Intention and Performance in China: The Role of Positive Affectivity, Chinese Values, Perceived Organizational Support and Constructive Controversy”. Journal of Occupational and Organizational Psychology, 80, 735-751.

Konovsky, M. A. and Cropanzano, R. (1991). "Perceived Fairness of Employee Drug Testing as a Predictor of Employee Attitudes and Job Performance”. Journal of Applied Psychology, Vol. 76 (5), 698-707.

Kwon, K., Bar, J., \& Lawler, J. J. (2010). High commitment HR practices and top performers: Impact on organizational commitment. Management International Review, 50, 57 80.

Lipponen, J., Olkkonen, M.E. and Myyry, L. (2004). "Personal Value Orientation as a Moderator in the Relationships Between Perceived Organizational Justice and its Hypothesized Consequences". Social Justice Research, Vol.17 (3), 275-292.

Lam, S.S.K., Schaubroeck, J., and Aryee, S., (2002). "Relationship between organizational justice and employee work outcomes: a cross-national study”, Journal of Organizational Behavior, 23, Pp. 1-18.

Loi, R., Hang-Yue, N. and Foley, S. (2006). "Linking Employees' Justice Perceptions To Organizational Commitment and Intention to Leave: The Mediating Role of Perceived Organizational Support”. Journal of Occupational and Organizational Psychology 79, 101-120.

Martin, Christopher L. and Bennett, Nathan (1996). "The Role of Justice Judgments in Explaining The Relationship Between Job Satisfaction and Organizational Commitment”, Group \& Organization Management, Vol. 21, No. 1.

Masterson, S. S., Lewis, K., Goldman, B. M., and Taylor, M. S., (2000). "Integrating justice and social exchange: The differing effects of fair procedures and treatment on work relationships", Academy of Management Journal, Vol. 43, No. 4, Pp. 738-748.

Meyer J.P., Allen, N.J. (1997), Commitment In Workplace, Theory, Research and Application, London, Sage Publications.

Moorman, Robert H., Gerald L. Blakely and Brian P. Niehoff., (1998). "Does Perceived Organizational Support Mediate The Relationship Between Procedural Justice And Organizational Citizenship Behavior?", Academy of Management Journal, Vol. 41 (3), Pp.351-357.

Niehoff, B. P. and Moorman, R. H. (1993): "Justice as a Mediator of The Relationships Between Methods of Monitoring and Organizational Citizenship Behavior”, Academy of Management Journal, 
Vol. 36, Pp. 527-556.

Nunnally, J.C. (1978) Psychometric Theory, $2^{\text {nd }}$ ed. (McGraw-Hill, New York).

Olkkonen, M. E., and Lipponen, J., (2006). "Relationships between organizational justice, identification with organization and work unit, and group-related outcomes", Organizational Behavior and Human Decision Processes, Vol. 100, No. 2, Pp. 202-215.

Orpen, Christopher (1994), "The Effect of Organizational Commitment on the Relationship Between Procedural and Distributive Justice”, The Journal of Social Psychology, 134(1), Pp. 135-136.

Özdevecioğlu, Mahmut (2003), "Algılanan Örgütsel Destek İle Örgütsel Bağlllık Arasındaki İlişkilerin Belirlenmesine Yönelik Bir Araştırma”, D.E.Ü.İI. B.F.Dergisi Cilt:18 Sayı:2, Yı1:2003, ss:113 130.

Pack, S., Jordan, J. S., Turner, B. A., \& Haines, D. J. (2007). Perceived organizational support and employee satisfaction and retention. Recreational Sports Journal, 31, 95-106.

Randall, M.L, Cropanzano, R., Bormaan, C.A., \& Birjulin, A. (1999). Organizational politics and organizational supports as predictiors of work attitudes, job performance, and organizational citizenship behavior. Journal of Organizational Behavior, 20, 159-174.

Rhoades, Linda and Robert Eisenberger (2002). "Perceived Organizational Support: A Review of The Literature", Journal Of Applied Psychology, Vol. 87 (4), Pp 698-714.

Rhoades, L., Eisenberger, S., \& Armeli, S. (2001). Affective commitment to the organization: The contribution of perceived organizational support. Journal of Applied Psychology, 86, 825-836.

Robbins, S.P.(2000) Organizational Behavior, Sixth Edition, Practice Hall, USA

Sax, L.J., Gilmartin S.K. and Bryant A.N. (2003). "Assessing Response Rates and Nonresponse Bias in Web and Paper Surveys". Research in Higher Education, Vol.44 (4), 409-431.

Schonlau, M., Fricker, R., Elliott M. (2002). Conducting Research Surveys via E-mail and the Web. Santa Monica, CA: RAND.

Settoon, Randall., Bennet, Nathan, and Liden Robert (1996). "Social Exchange in Organizations: perceived Organizatioanl Support, Leader-member Exchange, and Employee Reciprocity", Journal of Applied Psychology, Vol. 81 (3), Pp. 219-227.

Shaffer, M.A., Harrison D. A., Gilley K.M., Luk, D.M. (2001). "Struggling For Balance Amid Turbulence on International Assignmint: Work- Family Cconflict, Support and Commitment". Journal of Management, 27, 99-121

Shore, Lynn McFarlane and Loise E. Tetrick (1991), "A construct Validity Study of the Survey of Perceived Organizational Support", Journal of Applied Psychology, Vol. (5), Pp .637-643.

Sweeney, P. D., \& McFarlin, D. B. (1993). Workers' evaluations of the "ends" and the "means": An examination of four models of distributive and procedural justice. Organizational Behavior and Human Decision processess, Vol. 55, No. 1,Pp. 23-40.

Sweeney, P. D., and McFarlin, D. B., (1997). "Process and outcome: gender differences in the assessment of justice", Journal of Organizational Behavior, Vol. 18, Pp. 83-98.

Tett, R. P., and Meyer, J. P. (1993). Job satisfaction, organizational commitment, turnover intention, and turnover: Path analysis based on meta-analytic findings. Personnel Psychology, 46, 259-293.

Töremen, Fatih and Tan, Çetin, (2010). "Eğitim örgütlerinde adalet: kavramsal bir çözümleme", Dicle Üniversitesi Ziya Gökalp Eğitim Fakültesi Dergisi, 14, 58-70

Yaylı, Ali and Serdar Çöp, (2009), "Türkiye ve Polonya'da Turizm Sektörü Çalışanlarının Örgütsel Adalet ve Örgütsel Bağlllık Algılarının Karşılaştırılması”, 17. Ulusal Yönetim ve Organizasyon Kongresi Bildiriler Kitabl, Pp.181-188.

Yıldız, Sibel (2008), Örgüt Külttürünün, İşten Ayrılma Eğilimi Ve Çalışan Verimliliği Üzerindeki Etkisi: Bir Ara Değişken Olarak Örgütsel Destek Algısı, Yayımlanmamış Yüksek Lisans Tezi, Abant İzzet Baysal Üniversitesi, Sosyal Bilimler Enstitüsü, Bolu. 